\title{
Erratum to: Effect of annealing on the properties of zinc oxide nanofiber thin films grown by spray pyrolysis technique
}

\author{
N. Sadananda Kumar • Kasturi V. Bangera • \\ G. K. Shivakumar
}

Published online: 3 May 2013

(c) The Author(s) 2013. This article is published with open access at Springerlink.com

\section{Erratum to: Appl Nanosci \\ DOI 10.1007/s13204-012-0190-9}

In the original publication of the article, the contents of Tables 1, 2 and 4 were swapped and published incorrectly, though the table legends have been published correctly. The correct orders of tables are given below.

Table 1 XRD data of as grown and annealed $\mathrm{ZnO}$ thin films

\begin{tabular}{lllllll}
\hline $\begin{array}{l}\text { Annealing } \\
\text { time }(\mathrm{h})\end{array}$ & $\begin{array}{l}\text { Angle } \\
\left({ }^{\circ} 2 \theta\right)\end{array}$ & Orientation & $D(\mathrm{~nm})$ & $\begin{array}{l}\delta \times 10^{-5} \\
\left(1 / \AA^{2}\right)\end{array}$ & $a(\AA)$ & $c(\AA)$ \\
\hline 0 & 31.30 & $(002)$ & 15.1 & 4.39 & 3.30 & 5.28 \\
1 & 31.62 & $(002)$ & 25.3 & 1.56 & 3.27 & 5.24 \\
4 & 31.57 & $(100)$ & 35.9 & 0.78 & 3.27 & 5.24 \\
6 & 31.55 & $(100)$ & 36.7 & 0.74 & 3.27 & 5.24 \\
\hline
\end{tabular}

Table 2 The variation of transmittance, conductivity, Urbach energy and band gap of as grown and annealed $\mathrm{ZnO}$ nanofiber thin films

\begin{tabular}{lcccc}
\hline $\begin{array}{l}\text { Annealing } \\
\text { time }(\mathrm{h})\end{array}$ & $\% T$ & $\sigma\left(\mathrm{S} \mathrm{m}^{-1}\right)$ & $E_{\mathrm{g}}(\mathrm{eV})$ & $E_{\mathrm{u}}(\mathrm{meV})$ \\
\hline 0 & 75 & 0.6 & 3.29 & 377 \\
1 & 79 & 16.0 & 3.28 & 264 \\
4 & 72 & 79.9 & 3.24 & 210 \\
6 & 66 & 91.2 & 3.20 & 278 \\
\hline
\end{tabular}

The online version of the original article can be found under doi:10.1007/s13204-012-0190-9.

N. Sadananda Kumar $(\bowtie) \cdot$ K. V. Bangera · G. K. Shivakumar Thin films Laboratory, Department of Physics, National Institute of technology Karnataka, Surathkal, 575025 Mangalore, India e-mail: sadanthara@gmail.com
Table 4 Comparison of transmittance and conductivity data of $\mathrm{ZnO}$ with AZO and ITO

\begin{tabular}{llll}
\hline Material & $\%$ Transmittance & Conductivity $(\mathrm{S} / \mathrm{m})$ & References \\
\hline ZnO & 74 & 79.9 & \\
AZO & 80 & $35.7 \times 10^{3}$ & Muiva et al. (2011) \\
ITO & 80 & $34.3 \times 10^{3}$ & Manoj et al. (2007) \\
\hline
\end{tabular}

Open Access This article is distributed under the terms of the Creative Commons Attribution License which permits any use, distribution, and reproduction in any medium, provided the original author(s) and the source are credited. 